\title{
The trophic ecology of the red swamp crayfish (Procambarus clarkii) in Mediterranean aquatic ecosystems: a stable isotope study
}

\author{
Paloma Alcorlo* and Angel Baltanás \\ Department of Ecology, Universidad Autónoma de Madrid, E-28049 Madrid, Spain. \\ * Corresponding author: paloma.alcorlo@uam.es
}

Received: $26 / 9 / 12$

Accepted: 26/2/13

\begin{abstract}
The trophic ecology of the red swamp crayfish (Procambarus clarkii) in Mediterranean aquatic ecosystems: a stable isotope study

The red swamp crayfish (Procambarus clarkii) is an invasive species in most of its current distribution range. As an omnivorous species that feeds on items of many trophic levels and is eaten by many others, it occupies a key trophic position within the invaded food webs. This trophic position, in combination with its active physiology, makes $P$. clarkii a suitable organism for ecotoxicological studies and, more specifically, a bioindicator of heavy metal pollution. These characteristics also make $P$. clarkii a likely vector of contaminants toward higher trophic levels. In this study, we (i) describe aquatic food webs in three contrasting Mediterranean wetlands in the lower Guadalquivir River Basin, southwestern Spain, each populated by invasive $P$. clarkii but having a different heavy metal concentration, (ii) assess the trophic role of crayfish and temporal trends in its diet using stable isotope analysis $\left(\delta^{13} \mathrm{C}\right.$ and $\left.\delta^{15} \mathrm{~N}\right)$, and (iii) assess the relationship of crayfish isotopic signatures to the content of heavy metals $(\mathrm{Cu}, \mathrm{Zn}, \mathrm{Pb}, \mathrm{Cd}, \mathrm{As})$ bioaccumulated in crayfish body tissues. We detected significant between-site differences in carbon and nitrogen isotopic signatures but found significant between-date differences only for nitrogen signatures. Betweensite changes in carbon and nitrogen isotopes were due primarily to variations in the relative contribution of autochthonous $v s$. allochthonous primary producers and shifts in crayfish abundance through time, respectively. Isotopic food web models were used to distinguish between systems driven by a detritus-based energy pathway and systems supported by detritus and primary producers. The trophic positions estimated for crayfish and other invertebrates at each site were low, suggesting the prevalence of omnivory and the occurrence of a trophic continuum rather than discrete levels. Isotopically, crayfish occupy a predator position in the observed food webs, which is consistent with the predominance of animal food sources in the species' diet. No significant changes were found between crayfish ontogenetic stages using isotopic ratios. The site with the highest concentration of heavy metals showed the highest $\delta^{13} \mathrm{C}$ and $\delta^{15} \mathrm{~N}$ values, and a significant correlation was found between five heavy metal elements ( $\mathrm{As}, \mathrm{Cd}, \mathrm{Zn} . \mathrm{Cu}, \mathrm{Pb})$ measured in crayfish and their nitrogen isotope signatures $(r=0.72, p<0.0001)$, thus reinforcing its contamination biomarker role.
\end{abstract}

Key words: Food webs, $\delta^{13} \mathrm{C}, \delta^{15} \mathrm{~N}$, crayfish, stable isotopes, Mediterranean wetlands, heavy metals.

\section{RESUMEN}

Ecología trófica del cangrejo rojo (Procambarus clarkii) en ecosistemas acuáticos mediterráneos: un estudio sobre isótopos estables

El cangrejo rojo (Procambarus clarkii) es una especie invasora en la mayor parte de su área de distribución actual. Ocupa un estatus trófico clave dentro de las redes tróficas invadidas al ser una especie omnívora que se alimenta de muchos recursos tróficos, además de ser presa de otros consumidores. Tal posición de especie clave, junto con su activa fisiología, hace que sea un vector potencial de contaminantes a posiciones superiores en las redes tróficas, y por lo tanto, un excelente bioindicador de contaminación por metales pesados que ha sido muy utilizado en estudios ecotoxicológicos. En este estudio describimos las redes tróficas de tres humedales mediterráneos de la cuenca del Bajo Guadalquivir (SO, España), que poseen densas poblaciones de $\mathrm{P}$. clarkii y que muestran diferentes grados de afección por contaminación de metales pesados, usando isótopos estables $\left(\delta^{13} C\right.$ and $\left.\delta^{15} N\right)$. Además, se explora la relación que existe entre las señales isotópicas y las concentraciones de metales pesados ( $\mathrm{Cu}, \mathrm{Zn}, \mathrm{Pb}, \mathrm{Cd}$, As) bioacumuladas en sus tejidos. Se detectaron diferencias significativas en las señales isotópicas de carbono y nitrógeno entre las diferentes localidades, mientras que las diferencias temporales sólo fueron reflejadas por la señal del nitrógeno. Los cambios medios que se dan en las señales del carbono y nitrógeno en cada localidad, 
son debidas a la contribución relativa de los productores primarios autóctonos respecto a la de los alóctonos y cambios en la abundancia de cangrejos a lo largo del tiempo, respectivamente. La descripción de las redes tróficas realizada a través de los isótopos estables distingue entre los sistemas con flujos energéticos basados en detritus, y los basados en productores primarios junto con detritus. Las posiciones tróficas estimadas para los cangrejos e invertebrados en cada localidad fueron bajas, sugiriendo que existe un predominio de la omnivoría y la existencia de un "continuo trófico" mas que la existencia de niveles discretos. Isotópicamente, los cangrejos ocupan una posición de depredador en las redes tróficas que concuerda con el predominio de recursos de origen animal en su dieta. No se encontraron cambios ontogenéticos en la dieta de los distintos estadios de cangrejo según las señales isotópicas. La localidad con una mayor contaminación de metales pesados mostró una relación directamente proporcional significativa con las señales isotópicas de $\delta^{13} C$ y $\delta^{15} N(\mathrm{r}=0.72$, $\mathrm{p}<0.0001)$, reforzando así su papel como biomarcador.

Palabras clave: Redes tróficas, $\delta^{13} \mathrm{C}, \delta^{15} \mathrm{~N}$, cangrejo, isótopos estables, humedales mediterráneos, metales pesados.

\section{INTRODUCTION}

Among the several alien species of freshwater crayfish that have been introduced in Spain during recent decades, the red swamp crayfish (Procambarus clarkii Girard) has been the most successful and therefore the most environmentally threatening of them all (Gutiérrez-Yurrita, et al., 1999). P. clarkii was introduced in 1973 at two aquaculture installations in Sevilla and Badajoz, southwestern Spain (Habsburgo-Lorena, 1983) and spread throughout the Mediterranean region and central Europe during the subsequent three decades (Alonso $e t$ al., 2000). Its broad ecological tolerance, rapid growth, high fecundity and resistance to diseases explain such achievement (Montes et al., 1993; Gherardi \& Barbaresi, 2000).

The establishment of red swamp crayfish populations in Mediterranean wetlands and rivers in southwestern Spain was so successful because of the similar environmental conditions with $P$. clarkii's homeland aquatic systems (the southeastern areas of the USA) (Geiger et al., 2005). The species' establishment in Spain was also greatly promoted by intentional and repeated translocations by humans for economic or recreational purposes (Montes et al., 1993). The presence of this alien species has significant impacts on the structure and functioning of the invaded aquatic ecosystems. An example of such an impact is the physical alteration of the habitat structure, primarily through shredding of macrophytes during feeding and indirectly through bioturbation of sediments (Geiger et al., 2005). These mechanisms are considered to be responsible for the change observed in many invaded ecosystems from a natural, macrophytedominated, transparent water equilibrium state to a turbid, eutrophic, phytoplankton-dominated equilibrium state (Anastácio \& Marques 1995; Angeler et al., 2001; Rodríguez et al., 2003). Because $P$. clarkii is an opportunistic, omnivorous feeder with high assimilation efficiencies that rapidly develops dense populations (GutiérrezYurrita et al., 1999), it is expected to have strong effects on aquatic food webs and to impact trophic levels both below (Ilhéu \& Bernardo, 1993, 1995; Gutiérrez-Yurrita et al., 1998) and above its own (Geiger et al., 2005; Tablado et al., 2010). Despite $P$. clarkii's major role in structuring aquatic food webs, information regarding the species' diet in natural habitats is scarce (Feminella \& Resh, 1986, 1989; D'Abramo \& Robinson, 1989; Ilhéu \& Bernardo, 1993, 1995; Gutiérrez-Yurrita et al., 1998; Alcorlo et al., 2004). Studies of food webs have traditionally been based on stomach content analyses for the placement of species at their proper trophic position (Hobson \& Welch, 1992). This approach, however, often relies on data gathered on a casual rather than on a regular basis making trophic models particularly susceptible to both the temporal and the spatial scales used (Paine, 1988). In recent years, the biological interpretation of changes in the relative abundance of naturally 
occurring stable isotopes of nitrogen $\left(\delta^{15} \mathrm{~N}\right)$ and carbon $\left(\delta^{13} \mathrm{C}\right)$ has provided an alternative method for characterising food web structures and dynamics (Peterson et al., 1985; Peterson \& Fry, 1987; Lajtha \& Michener, 1994; Hershey \& Peterson, 1996; Gannes et al., 1998; Inger \& Bearhop 2008; Martínez del Río et al., 2009). This approach is based on the fact that stable-isotope ratios of nitrogen and carbon in the tissues of consumers reflect those in their prey in a predictable manner (DeNiro \& Epstein, 1978, 1981).

In addition, the polytrophic character of crayfish has important consequences for ecosystem management because of the role that these animals play in the transport of xenobiotic substances throughout the food web. $P$. clarkii can ingest and eventually store large amounts of heavy metals in its tissues (Maranhao et $a l ., 1995)$ and is able to adjust, using complex physiological mechanisms, to survive in polluted environments (Naqvi \& Flagge, 1990; Naqvi and Howel, 1993; Allison et al., 2000). P. clarkii has therefore been widely used as a biomarker (Depledge \& Fossi, 1994; Anderson et al., 1997a, 1997b; Schilderman et al., 1999; Schlenk, 1999; Antón et al., 2000; Alcorlo et al., 2006; MartínDíaz et al., 2006; Vioque-Fernández et al., 2007; Vioque-Fernández et al., 2009; Faria et al., 2010; Suárez-Serrano et al., 2010) to efficiently trace the relocation of heavy metals from nonbiological (primarily sediments) to biological compartments (food webs) in the ecosystem.

The estimation of the amount of pollutants that $P$. clarkii mobilises and stores as biomass is ecologically relevant because this species is now the major prey item for many endangered and legally protected vertebrate species in the Lower Guadalquivir Basin (Adrian \& Delibes, 1987; Palomares \& Delibes, 1991; Senra \& Alés, 1992; Correia, 2001; Tablado et al., 2010). Pollution effects can potentially travel far from the source area through the trophic relationships that link crayfish with wide-ranging predator species (e.g., herons, spoonbills, storks, otters).

The general aim of the present study is to describe the trophic position of $P$. clarkii and its role as a heavy metal bioindicator in three Mediterranean wetlands exposed to different land-uses (one in a natural protected area, one surrounded by agricultural land and one affected by a toxic mine spill). Our specific aims are as follows: 1) to describe the food webs using carbon and nitrogen stable isotopes, with emphasis on temporal and habitat variations in the diet of P. clarkii; 2) to determine whether $P$. clarkii occupies the same trophic position in each of the three environments; 3 ) to investigate whether isotopic signatures describe changes in diet in relation to crayfish ontogeny; and 4) to analyse the relationship between nitrogen isotopic signatures and heavy metal bioaccumulation in $P$. clarkii tissues.

Our hypothesis is that the isotopic descriptions of the assembled food webs in three types of aquatic ecosystem will reflect the differing structures of the food web patterns developed. According to this hypothesis, 1) the isotopic signals of crayfish will reveal distinct positions in each system depending on the unequal contribution of the exploited food resources and the ontogenetic shifts in diet, and 2) the nitrogen isotopic signature of $P$. clarkii will be correlated with the levels of heavy metal contamination because of the dissimilar communities developed at each site.

\section{METHODS}

\section{Study area}

The study was conducted in three tributaries of the Lower Guadalquivir River (SW Spain) close to the northern boundary of Doñana National Park (Fig. 1). The three sampling sites are subject to differing land-use and anthropogenic pressures and have contrasting morphological features in terms of the nature and grain size of stream bed sediments and of the channel shape (Montes et al., 1998).

Site 1 (Brazo del Este, UTM: 29SQB633117) is located in a section of a stream that collects water runoff with a high content of pesticides and fertilisers from the surrounding rice fields (Cano \& Ocete, 1997; Vioque-Fernández et al., 2009). The agricultural activity in this area has resulted in the discharge of pesticides with lead $(\mathrm{Pb})$, copper $(\mathrm{Cu})$ and arsenic (As) (http://npic. 


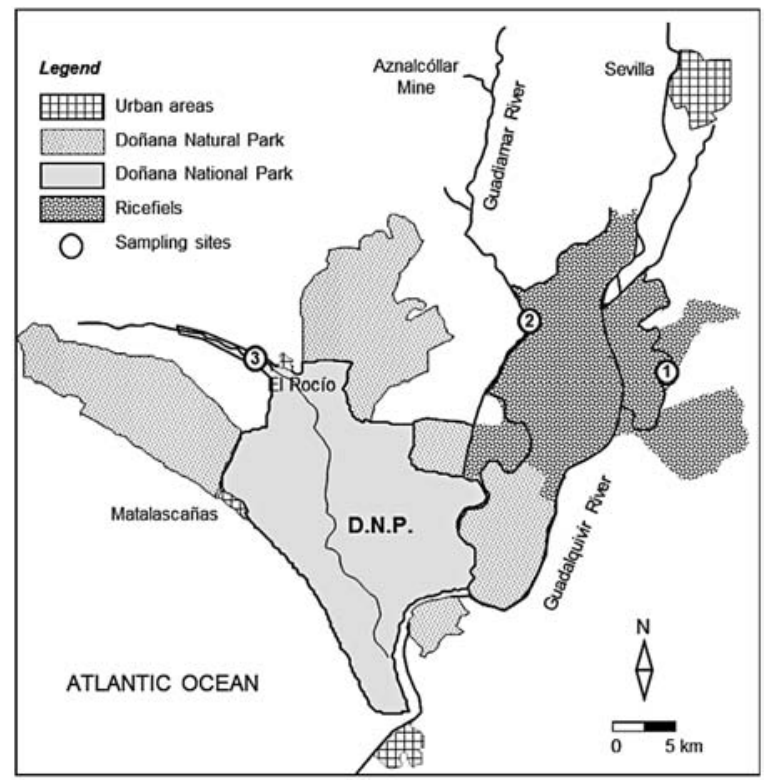

Figure 1. Schematic map of the studied area, sampling stations and mine location. 1.-Brazo del Este, 2.-Puente de los Vaqueros, 3.-Charco de la Boca. Mapa de la zona de estudio, donde se muestran las estaciones de muestreo y la mina. 1.-Brazo del Este, 2.-Puente de los Vaqueros, 3.-Charco de la Boca.

orst.edu/ingred/aifact.html) into the surrounding aquatic ecosystems for many years (VioqueFernández et al., 2009). The riverbanks are covered by well-developed cattail (Typha sp.) stands. The sediment is muddy and rich in clay and silt and has a thick, organic-rich, black layer on top.

Site 2 (Puente de los Vaqueros, UTM: 29SQB495168) is located in the lower watercourse of the Guadiamar Basin (Fig. 1). Although the Guadiamar River was formerly one of the main tributaries of both the Guadalquivir River and its associated marshland, it is nowadays dramatically transformed in a multitude of channels that distribute and collect irrigation water to and from the surrounding rice fields. In April 1998, the entire basin was severely affected by a toxic spill from the Aznalcóllar mine that released $5 \mathrm{Hm}^{3}$ of acid water and metalrich sludge (As-0.6\%; $\mathrm{Pb}-1.2 \% ; \mathrm{Zn}-0.8 \%$ dry weight, and other metals) (Meharg et al., 1999). In addition to mining activity, the stream also receives sewage dumping from the nearby urban areas (Prat et al., 1999). In the sampling area, the emergent vegetation on the banks has been reduced to small patches of common reed (Phragmites australis) and cattail (Typha sp.). The riverbed sediments are very rich in silt, which causes the water to be turbid most of the time.

Site 3 (Charco de la Boca, UTM: 29SQB 227121) is located in a wetland within the boundaries of Doñana National Park (Fig. 1). The entire area is covered by pines (Pinus pinea) growing on sandy soils. The littoral zone of the wetland is rich in silt and clay and is occupied by belts of Phragmites australis and cattail Typha sp., which provide shelter and food to many waterfowl and other bird species (Montes et al., 1998).

\section{Field data collection}

Samples were collected during periods when crayfish were very abundant and their populations included individuals of varying sizes and developmental stages: autumn (November 2000date 1 and 2001-date 3; the end of the growing season for crayfish), and mid-Spring (April 2001-date 2; which is the growing season). Three replicate samples for each of the categories used in the food web (i.e., fish, crayfish, invertebrates -zooplankton and zoobenthos-, aquatic flora, detritus and sediments) were taken on each date. Limnological descriptors [depth $(\mathrm{cm})$, turbidity (cm, Secchi disk depth), water temperature $\left({ }^{\circ} \mathrm{C}\right)$ and dissolved oxygen (mg $\mathrm{l}^{-1}$ and \%, WTWoxymeter), conductivity ( $\mu \mathrm{cm}^{-1}$, WTW LF96conductivimeter), and $\mathrm{pH}$ (Merck- indicators paper)] were measured in situ. Sediment samples were obtained with a core-sampler (54 mm inner diameter, $50 \mathrm{~cm}$ height). The upper layer ( $5 \mathrm{~cm}$ deep), where most of the detritus is stored, was sliced out and kept in a polyethylene bag hermetically closed. This fraction containing the organic matter in the sediment will be referred to hereafter as detritus. The so-called phytoplanktonic fraction, a mixture of true algae plus particulate organic matter $(0.45-100 \mu \mathrm{m})$, was collected on a pre-ashed $\left(500{ }^{\circ} \mathrm{C}\right.$ for $\left.4 \mathrm{~h}\right)$ glass fibre filter (Whatman, $\mathrm{CF} / \mathrm{C}$ ) and stored in a hermetic polyethylene bag kept in darkness. Helophyte samples were obtained from emergent plant species (Phragmites australis in sites 2 and 3, and Typha in all sites). Samples of submerged 
vegetation were restricted to the terrestrial grass Cynodon dactylon in sites 2 and 3. Healthy green leaves and stems were handpicked from various stands and put in hermetic polyethylene bags. A hand net (250 $\mu \mathrm{m}$ mesh size) was used for collecting invertebrates. Samples were obtained by filtering water along $50 \mathrm{~m}$ long transects for five to ten minutes. Material collected in this way was placed in polyethylene bottles $(500 \mathrm{ml})$. Fish, crayfish and shrimp were collected at each site using 10 shrimp traps ('nasa camaronera'). The traps were checked after $24 \mathrm{~h}$. When captures were too small (e.g., $n<10$ individuals), the traps were left in the field for a second day. Captured animals were individually placed in hermetic plastic bags.

All sediment and biological samples were kept refrigerated $\left(4^{\circ} \mathrm{C}\right)$ until freezing on the same day of collection. The samples remained frozen until they were prepared for stable isotope analysis. Crayfish selected for the analysis of heavy metal contents (ten individuals from each site) were measured in situ for body length (distance from the edge of the rostrum to the telson, expressed in $\mathrm{cm}$ ) and mass (using a portable Scaltec balance and expressed in $g$ with an accuracy of $0.1 \mathrm{~g}$ ). An additional sample of zooplankton and benthos was taken and fixed ( $4 \%$ neutralised formaldehyde) for further taxonomic identification.

\section{Stable isotope analysis}

For the isotopic analysis of sediments, 30-50 mg of each frozen sample was thawed, placed in a $250 \mathrm{ml}$ Erlenmeyer flask, and suspended in $100 \mathrm{ml}$ of $0.2 \mathrm{~N} \mathrm{HCl}$ for $24 \mathrm{~h}$ at room temperature to remove carbonates. The sediments were then rinsed thoroughly with deionised water and dried at $60{ }^{\circ} \mathrm{C}$ until no further water loss occurred (Cifuentes et al., 1988; Bernasconi et al., 1997). The samples were then homogenised using a mortar and pestle and stored dry in $15 \mathrm{ml}$ vials until analysed.

Filters of phytoplankton samples were dried at $60{ }^{\circ} \mathrm{C}$ until no water loss was recorded and stored dry in vials until analysed (Gearing et al., 1984). Macrophyte and helophyte samples were thawed, epiphytic material was removed from leaves and stems by gentle wiping and washed with deionised water, and all of these materials were dried at $60{ }^{\circ} \mathrm{C}$ (LaZerte \& Szalados, 1982; Boon \& Bunn, 1994). The dried periphyton material was homogenised using a mortar and pestle and stored dry in $15 \mathrm{ml}$ vials until analysed (France, 1999). The aquatic plant tissues were milled using an analytical mill (model IKA-A10).

The dominant planktonic and benthic taxa were sorted by hand from the thawed samples. In several cases, insects and microcrustaceans had to be pooled by taxonomic groups (i.e., Order) to obtain sufficient material for isotopic analysis. Ostracods (crustaceans with a calcareous carapace) were suspended in a solution of $0.2 \mathrm{~N} \mathrm{HCl}$ for $24 \mathrm{~h}$ at room temperature to remove carbonates. The samples were then rinsed thoroughly with deionised water, dried at $60{ }^{\circ} \mathrm{C}$ until no water loss was recorded, homogenised with a mortar and pestle and stored dry in $15 \mathrm{ml}$ vials until analysed (Gearing et al., 1984).

The abdominal muscles of crayfish (France, 1996a) and muscle samples above the lateral line of fish (Kwak \& Zedler, 1997) were dissected after thawing of the samples. The samples were rinsed thoroughly with deionised water, dried, powdered, and stored at room temperature (20 to $25^{\circ} \mathrm{C}$ ) until isotope analysis.

Stable carbon and nitrogen analyses were performed on $1 \mathrm{mg}$ subsamples of homogenised materials by loading them into tin cups and combusting at $1800^{\circ} \mathrm{C}$ in a Carbo Erba 1108 CHNS elemental analyser. The resultant $\mathrm{CO}_{2}$ and $\mathrm{N}_{2}$ gases were analysed using a Micromass Isochrom continuous-flow isotope ratio mass spectrometer (CFIRMS) with every 9 unknowns separated by two or three laboratory standards (NBS22, sucrose, atropine, benzoic).

Stable isotope abundances were expressed in $\delta$ notation as the deviation from standards in parts per thousand (\%o) according to the following equation:

$$
\delta X=\left[\left(R_{\text {sample }} / R_{\text {standard }}\right)-1\right] \times 1000
$$

were $X$ is the isotope ${ }^{15} \mathrm{~N}$ or ${ }^{13} \mathrm{C}$, and $R$ is the corresponding ratio ${ }^{15} \mathrm{~N} /{ }^{14} \mathrm{~N}$ or ${ }^{13} \mathrm{C} /{ }^{12} \mathrm{C}$. The $R_{\text {standard }}$ for ${ }^{15} \mathrm{~N}$ is that for atmospheric $\mathrm{N}_{2}$ (air) and the 
$R_{\text {standard }}$ for ${ }^{13} \mathrm{C}$ is that for Pee Bee Belemmnite (PDB) limestone formation. Based on numerous measurements of organic and inorganic standards by the lab that performed the analyses, the precision of these measurements was estimated to be \pm 0.1 and $\pm 0.2 \%$ for carbon and nitrogen, respectively.

\section{Isotopic models}

The trophic position of food web items at each site was estimated assuming a constant enrichment value of $3.4 \%$ in the nitrogen stable isotope, in accordance with previous studies performed in other aquatic ecosystems (Minagawa \& Wada, 1984; DeNiro \& Epstein, 1981; Whitledge \& Rabeni, 1997; Ponsard \& Arditi, 2001). Accordingly, the trophic level was computed by the following equation:

$$
\mathrm{TL}=1+\frac{\left(D_{p}-D_{b}\right)}{3.4}
$$

where TL is the trophic level of a consumer and $D_{p}$ is the $\delta^{15} \mathrm{~N}$ value of the whole body tissues of consumers in the case of insects and microcrustaceans or the $\delta^{15} \mathrm{~N}$ value of the consumer's muscle tissue in the case of fish and crayfish (\%o). $D_{b}$ is the baseline $\delta^{15} \mathrm{~N}$ value; i.e., the isotopic value of the main food sources of the consumer. Detritus was assumed to be the main food source for all of the consumers in the food web except the microcrustaceans, for which phytoplankton were assumed to be the main food source.

The above approach is a simplistic way to summarise the various enrichment factors that might occur between different food web items. Further studies are required to identify more precisely the $\delta^{15} \mathrm{~N}$ enrichment factors between consecutive trophic levels. Alternatively, the use of an average enrichment factor of $3.4 \%$, as actually found in several aquatic food webs, appears to provide a good estimate of the trophic interactions that we are trying to elucidate.

We used a concentration-weighted linear mixing model of $\delta^{15} \mathrm{~N}$ and $\delta^{13} \mathrm{C}$ values (Phillips \& Koch 2002; http://www.epa.gov.wed/pages/ models.htm) to estimate the proportion of the crayfish diet allocated to each of the major food items (invertebrates, vegetative material or detritus) as determined in previous conventional crayfish dietary studies that analysed stomach contents and were performed at the same sites (Gutiérrez Yurrita et al. 1998, Alcorlo et al., 2004) and in other studies (Brown, 1990; Whitledge \& Rabeni, 1997; Evans-White et al., 2001). This model assumes that for each element, the contribution of a source is proportional to the contributed mass times the elemental concentration in that source. Isotopic values for food sources must be adjusted by the appropriate fractionation values to account for trophic fractionation (Phillips \& Koch, 2002). In this study, we used 3.4 and $0.8 \%$ fractionation factors for nitrogen and carbon isotopes, respectively (Ponsard \& Arditi, 2001). The elementary compositions of $\mathrm{C}$ and $\mathrm{N}$ of the food web items determined were analysed with an elemental analyser (Carbo Erba 1108-CHNS) during the isotopic determinations.

Such models have both mathematical and biological limitations (Ben-David \& Shell, 2001; Phillips, 2001; Phillips \& Gregg, 2001). An overestimation of the contribution to the diet may occur if one source has a signal similar to that of the sink, and exact solutions are not possible unless all of the end members are included. The ranges of source contributions can be determined. The breadth of these ranges depends on the geometry of the mixing space (e.g., mixing triangles) and the similarity of the source and mixture isotopic signatures. When the mixture lies near the periphery of the convex polygon connecting the sources, the sources on that side of the mixing diagram predominate and the ranges of the possible contributions from each source are well constrained. We followed the suggestion of BenDavid \& Shell (2001) and the procedure of Jones \& Waldron (2003), and used these models as a heuristic tool to investigate the patterns of our data.

\section{Heavy metal analysis}

Heavy metal analyses of arsenic (As), copper $(\mathrm{Cu})$, zinc $(\mathrm{Zn})$, cadmium $(\mathrm{Cd})$ and lead $(\mathrm{Pb})$ were performed for the crayfish sampled in November 2001. Because P. clarkii is exploited 
for commercial use in the study area and the legal limits for human consumption are expressed in fresh weight, we expressed the heavy metal concentrations as $\mu \mathrm{g} \cdot \mathrm{g}^{-1}$ fresh weight.

The entire body of each crayfish was powdered and homogenised, and a 2-g subsample was digested in $10 \mathrm{ml}$ of nitric acid $(65 \%)$ for at least $30 \mathrm{~min}$. A posterior microwave digestion was performed using a CEM Microwave Digestion System 2100 and following the protocol App. Note BI-7 "EPA 3052". The samples were then cooled, filtered (Whatman fiber glass filters, $47 \mathrm{~mm}$ diameter), brought to a volume of $100 \mathrm{ml}$ with deionised water, and each heavy metal item was analysed following the appropriate procedure. As and $\mathrm{Pb}$ were measured using Electrothermal Atomic Absorption Spectrometry with a graphite furnace. $\mathrm{Cd}, \mathrm{Zn}$ and $\mathrm{Cu}$ were measured using Inductively Coupled Plasma Emission Spectroscopy (EPA 6010 B).

\section{Statistical analyses}

The $\delta^{13} \mathrm{C}$ and $\delta^{15} \mathrm{~N}$ values estimated in each biological compartment of the food web were compared simultaneously between sites, dates and their interaction (date $\times$ site), using a multi-way analysis of variance (MANOVA) with the Wilks' lambda statistic. Certain samples in which only one of the $\delta$ values was available were excluded from the analysis. When post-hoc comparisons were required, we used Tukey's Honestly Significant Difference test (HSD). The normality of distributions was assessed by the inspection of normal plots. Departures from homogeneity of variances were assessed by Levene's test. Log-transformation of dependent variable was performed when necessary after exploring the correction of the heteroscedasticity of the transformed data.

A two-sample $t$ test for a two-tailed hypothesis was performed to assess the variation in mean $\delta{ }^{15} \mathrm{~N}$ values resulting from ontogenetic changes between young and adult crayfish.

Multiple correlation and regression analyses were performed to determine whether crayfish nitrogen stable isotope abundances were influenced by the heavy metal contents measured at all sites pooled together and at each site separately.

\section{RESULTS}

\section{Limnological parameters and community composition}

The three aquatic ecosystems sampled are characterised by their shallowness and a slightly saline character (Table 1). Sites 1 and 2 have conductivity and $\mathrm{pH}$ values that are higher than those of site 3. This finding is most likely due to the nature of the underlying geological materials, which are sandier and more acid in the area of site 3 .

The community composition in the studied sites is shown in APPENDIX 1 (www.limnetica.net/internet). Crustaceans, particularly cla-

Table 1. Ranges of variation of physico-chemical parameters of water at the three sampling sites. Rangos de variación de los parámetros físico-químicos del agua en las tres estaciones de muestro.

\begin{tabular}{|c|c|c|c|c|c|c|c|}
\hline \multirow{2}{*}{ Sampling site } & $\mathrm{Z}$ & Secchi & $\mathrm{T}$ & Conductivity & \multirow{2}{*}{$\mathrm{pH}$} & $\mathrm{O}_{2}$ & $\mathrm{O}_{2}$ \\
\hline & $(\mathrm{cm})$ & $(\mathrm{cm})$ & $\left({ }^{\circ} \mathrm{C}\right)$ & $\left(\mu \mathrm{S} \cdot \mathrm{cm}^{-1}\right)$ & & $\left(\mathrm{mg} \cdot \mathrm{l}^{-1}\right)$ & $(\%)$ \\
\hline \multicolumn{8}{|l|}{ Site 1} \\
\hline mean & 40.58 & 10.50 & 19.10 & 3296.20 & 8.02 & 5.84 & 90.60 \\
\hline range & $24.5-57$ & $6-15$ & $7.3-26.5$ & $2600-4711$ & $7.5-8.5$ & $1.9-10.31$ & $78-103.2$ \\
\hline \multicolumn{8}{|l|}{ Site 2} \\
\hline range & $24-67$ & $7-12$ & $11.2-28.9$ & $1173-3334$ & $7-8.5$ & $6.08-17.6$ & 58.5-184 \\
\hline \multicolumn{7}{|l|}{ Site 3} & 56.40 \\
\hline range & $7-37.5$ & $7-15$ & $11-16.9$ & $425-730$ & $6.5-8$ & $3.8-7.48$ & $39-73$ \\
\hline
\end{tabular}


docerans and copepods, and aquatic bugs (Insecta: Heteroptera) were the most species-rich animal groups. For certain rare taxa (ostracods and mayflies) it was not possible to obtain sufficient biomass for the stable isotope analyses, and these taxa were therefore excluded from the statistical analysis. Rotifers and ciliates were also excluded because of their low sampled biomass.

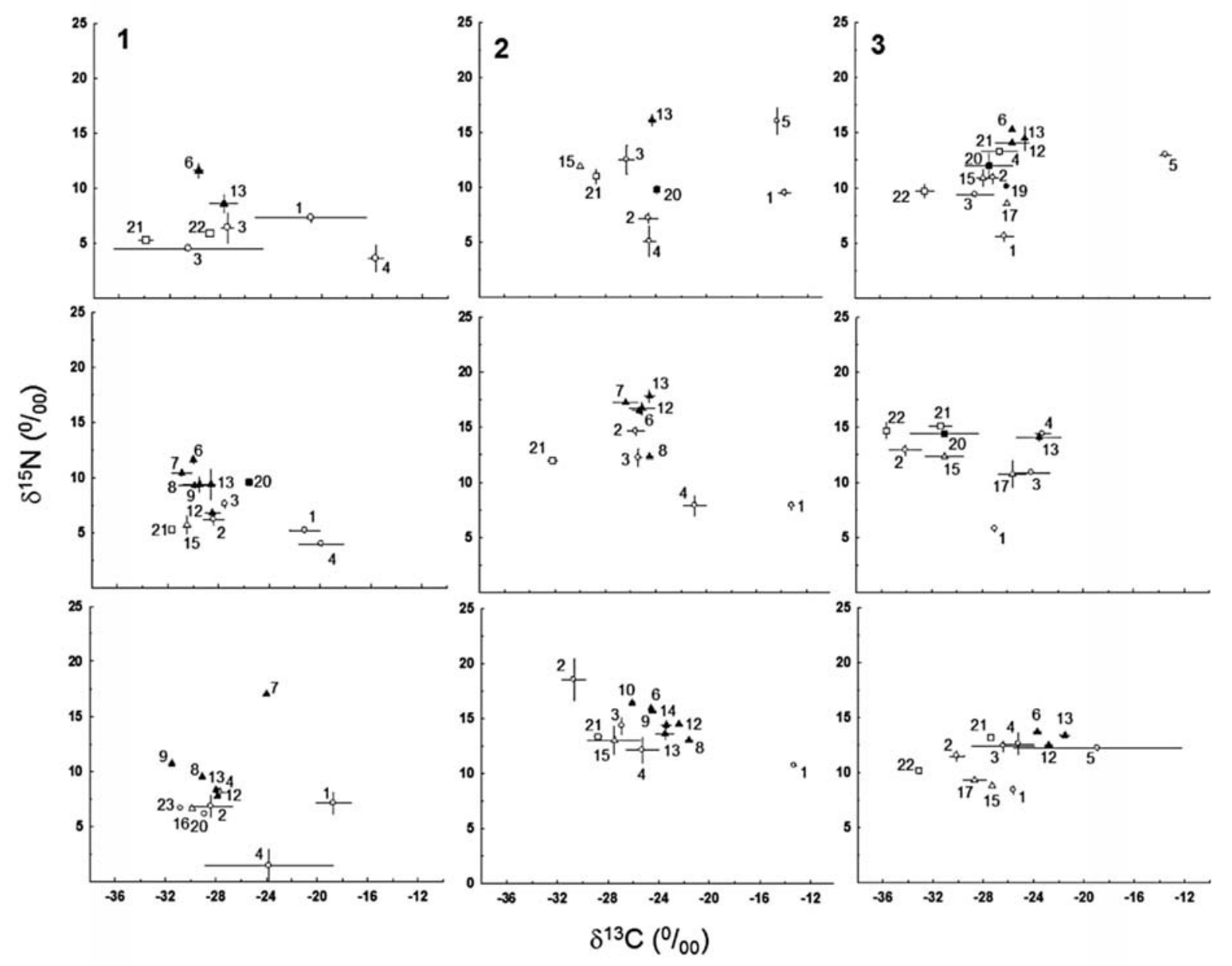

Figure 2. Stable isotope ratios for carbon $\left(\delta^{13} \mathrm{C}, \%\right.$, mean \pm S.D. $)$ and nitrogen $\left(\delta^{15} \mathrm{~N}, \%\right.$, mean \pm S.D. $)$ for food web components at each of the sampling sites (upper: November 2000, middle: April 2001, lower: November 2001). Trophic items are as follows: 1.-detritus, 2.-phytoplankton, 3.-helophytes, 4.-periphyton, 5.-submersed macrophytes, 6.-Gambusia holbrooki, 7.-Anguilla anguilla, 8.-Liza ramada, 9.-Cyprinus carpio, 10.-Barbus sclateri, 11.-crayfish $(<3 \mathrm{~cm}), 12 .-\mathrm{crayfish}(<7 \mathrm{~cm}), 13$.crayfish $(>7 \mathrm{~cm})$, 14.-Palaemon serratus (shrimp), 15.-heteroptera, 16.-odonata, 17.-coleoptera, 18.-ephemeroptera, 19.-gastropoda, 20.-diptera, 21.-copepoda, 22.-cladocera, 23.-microcrustaceans (copepoda and cladocera). Trophic categories are symbolised as: 0 primary producers, $\bullet$ invertebrate herbivores (ephemeroptera and gastropoda), $\triangle$ invertivores (heteroptera and odonata), omnivores (fish, shrimp and crayfish), $\mathbf{\Delta}$ detritivores (diptera), filter feeders (copepoda and cladocera). Razones isotópicas de carbono ( $\delta^{13} C, \%$, media \pm D.E.) y nitrógeno $\left(\delta^{15} \mathrm{~N}, \%\right.$, media \pm D.E.) para los componentes de la red trófica de las tres estaciones (arriba: noviembre 2000, en el medio: abril 2001, debajo: noviembre 2001). Los recursos tróficos son los siguientes: 1.-detritus, 2.-fitoplancton, 3.-helófitos, 4.-perifiton, 5.-macrófitos sumergidos, 6.-Gambusia holbrooki, 7.-Anguilla anguilla, 8.-Liza ramada, 9.-Cyprinus carpio, 10.-Barbus sclateri, 11.-cangrejos $(<3 \mathrm{~cm})$, 12.-cangrejos $(<7 \mathrm{~cm})$, 13.-cangrejos $(>7 \mathrm{~cm})$, 14.-Palaemon serratus $($ camarones $)$, 15.-heterópteros, 16.-odonatos, 17.-coleópteros, 18.-efemerópteros, 19.-gasterópodos, 20.-dípteros, 21.-copépodos, 22.-cladóceros, 23.-microcrustáceos (copépodos + cladóceros). Categorías tróficas simbolizadas como: ○ productores primarios, $\bullet$ invertebrados herbívoros (efemerópteros y gasterópodos), $\triangle$ invertívoros (heterópteros y odonatos), omnívoros (peces, camarones y cangrejos), detritivoros (dípteros), fitradores (copépodos y cladóceros). 
Food web structure revealed through the use of stable isotopes

MANOVA showed no significant interaction (date $\mathrm{x}$ site) $(\lambda$ Wilks' $=0.97$, Rao's $\left.R_{(8,594)}=1.03, p=0.4\right)$ but did show significant differences between dates $(\lambda$ Wilks' $=0.64$, Rao's $\left.R_{(4,594)}=36.13, p<0.0001\right)$ and sites $(\lambda$ Wilks' $=0.96$, Rao's $R_{(4,594)}=2.67, p=0.03$ ) for $\delta^{13} \mathrm{C}$ and $\delta^{15} \mathrm{~N}$ values, suggesting that the space and time factors have independent effects on the isotope values. Indeed, significant differences on $\delta^{15} \mathrm{~N}\left(F_{(2,298)}=3.72, p=0.02\right)$ were observed only for dates 2 and 3 (Tukey's HSD test; $p=0.025$ and $p=0.018$, respectively), but no significant differences were observed for $\delta^{13} \mathrm{C}$. The $\delta^{15} \mathrm{~N}$ values for site 2 increased through time, as follows: November $2000<$ April $2001<$ November 2001. In regard to carbon isotopes, no significant differences in $\delta^{13} \mathrm{C}$ were observed, except for the last date on site 3 (Tukey's HSD test, $p=0.026$ ).
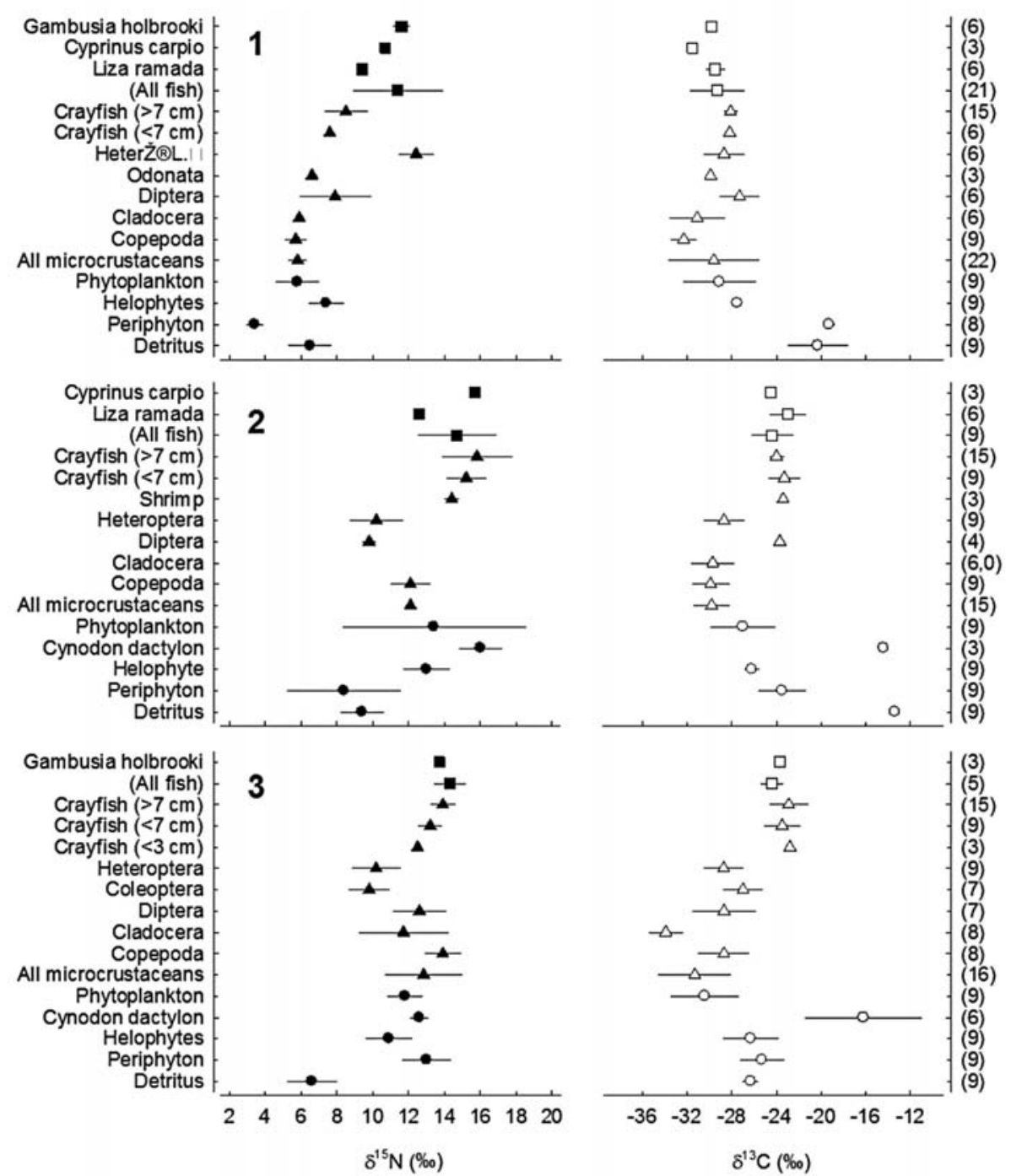

Figure 3. Stable nitrogen and carbon isotope concentration in food web components of the three sites during the sampling period. Sample sizes are given in parentheses following the names of species. Circle $(\bullet)$ : primary producers; triangle $(\boldsymbol{\Lambda}):$ invertebrates; square (ם): vertebrates. Concentración de isótopos estables de carbono y nitrógeno de los componentes de las redes tróficas de las tres estaciones durante el periodo de muestreo. Círculos: productores primarios, triángulos: invertebrados, cuadrados: vertebrados. 
The average whole system content of $\delta^{13} \mathrm{C}$ and $\delta^{15} \mathrm{~N}$ was highest for site 2 (which was affected by the heavy metals from the toxic spill), intermediate for site 3 , and lowest for site $1\left(\delta^{13} \mathrm{C}: F_{(2,298)}=15.48, p<0.0001 ; \delta^{15} \mathrm{~N}\right.$ : $\left.F_{(2,298)}=58, p<0.0001\right)$ (Fig. 2).

Detritus and periphyton drove the food webs in the habitats with soft and muddy bottom, i.e., sites 1 and 2, whereas the trophic dynamics in site 3 (which had a sandy bottom) were driven primarily by detritus and submersed vegetation (Fig. 2). The higher trophic positions in all of the systems were occupied by fish and crayfish, with crustaceans and insects at intermediate positions.

\section{Natural abundance of $\delta^{13} \mathrm{C}$ and $\delta^{15} \mathrm{~N}$}

The range values of $\delta^{13} \mathrm{C}$ for the three sites differed mainly in their basal components. For site 1 , the lowest and highest mean values corresponded to copepods and periphyton, respectively $(-34.3 \pm 1.2 ;-19.3 \pm 0.5 \%$, APPENDIX 2, www.limnetica.net/internet). Similarly, copepods at site 2 had the lowest $\delta^{13} \mathrm{C}$ value $(-29.9 \pm 1.7 \%$ while detritus had the highest value $(-13.4 \pm 0.4 \%$ ) (APPENDIX 3, www. limnetica.net/internet). For Site 3, the lowest value was found for cladocerans $(-33.9 \pm 1.4 \%$ ) and the highest value was found for the submersed grass Cynodon dactylon (-16.2 $\pm 5.2 \%$ ) (APPENDIX 4, www.limnetica.net/internet).

The $\delta^{15} \mathrm{~N}$ values for the three systems fluctuated in a variable manner. For sites 1 and 2 , the lowest $\delta^{15} \mathrm{~N}$ values were found for periphyton $(3.4 \pm 0.5 \%$ and $8.4 \pm 3.2 \%$ respectively) and the highest values were found for eels, Anguilla anguilla $(13.7 \pm 3.6 \%$ and $17.2 \pm 0.2 \%$, respectively) (APPENDIX 2 and 3). Finally, $\delta^{15} \mathrm{~N}$ values in site 3 fluctuate between $6.61 \pm 1.42 \%$ for detritus to $14.3 \pm 0.9 \%$ for the all-fish sample (APPENDIX 4).

The trophic positions were very close together, and very short trophic distances were found between species. The lowest crayfish values were found for site 1 (APPENDIX 2-4). For a better understanding of these variations in the $\delta^{13} \mathrm{C}$ and $\delta^{15} \mathrm{~N}$ ratios, we constructed an isotope scaling for the different compartments analysed for each system over the entire sampling period (Fig. 3). Adult crayfish always appeared in higher trophic positions than juveniles. No significant differences were found between the $\delta^{15} \mathrm{~N}$ values of juvenile and adult crayfish, except for site $3\left(t_{2(0.05)}=-2.68, p=0.016\right)$ (APPENDIX 2-4; Figs. 3 and 4).

\section{Trophic role of red swamp crayfish: applying a mixed model}

We estimated the resources most frequently used by crayfish using two sources: stable isotopes and traditional diet studies that were performed in the same geographic area (Gutiérrez-Yurrita et al., 1998; Alcorlo et al., 2004). The results of the application of the concentration-weighted mixing model using the equations proposed by Phillips and Koch (2002) were inconsistent with the isotopic data for site 1 but fit well with the isotopic data from the other sampling sites (Table 2).

\section{Nitrogen stable isotope ratios and heavy metals}

The highest concentrations of heavy metals in crayfish were found for site 2 , except for As

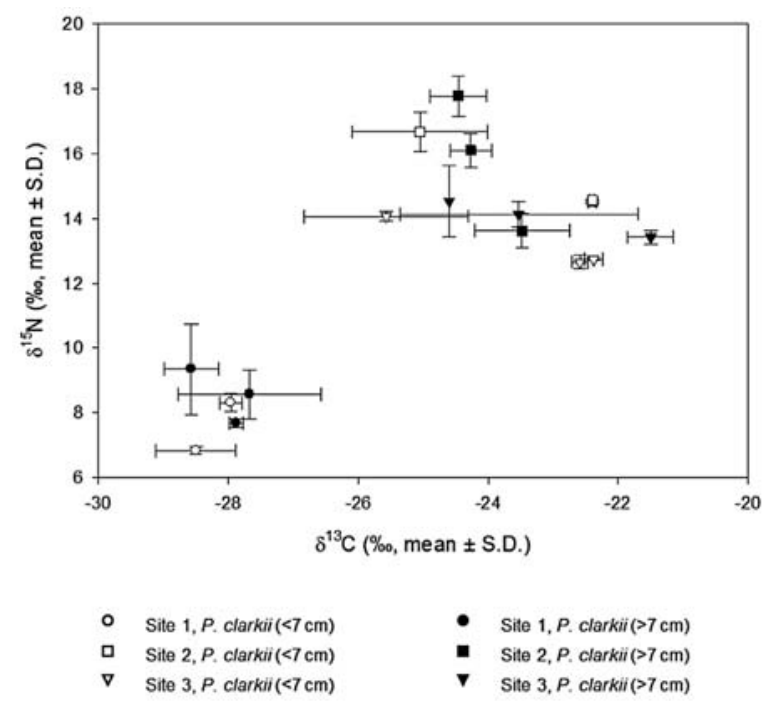

Figure 4. Stable nitrogen and carbon isotope concentration for juvenile and adult crayfish at the three sites (site 1, $\mathrm{n}=9,15$; site $2, \mathrm{n}=9,15 ;$ site $3, \mathrm{n}=6,15)$. Concentración de isótopos estables de carbono y nitrógeno de los cangrejos juveniles y adultos de las tres estaciones (Estación 1, $n=9$, 15; estación $2, n=9,15$; estación 3, $n=6,15$ ). 
which was higher at site 1 (Fig. 5). The $\mathrm{Cu}$ and $\mathrm{Pb}$ concentrations were well above the legal limits for heavy metal content in crustacean foodstuffs included in the Spanish law and EC Regulation No. 1881/2006 (20 ppm and $0.3 \mathrm{ppm}$ for $\mathrm{Cu}$ and $\mathrm{Pb}$, respectively). Arsenic (As) concentrations were high at each of the sites $(0.56-0.98$, $0.36-2.04$ and $0.79-1.02 \mu \mathrm{g} \mathrm{g}^{-1}$ or ppm for sites 1,2 , and 3 , respectively) when compared with the provisional tolerable daily intake suggested by the European Food Safety Authority $\left(2 \mu \mathrm{g} \mathrm{kg} \mathrm{g}^{-1}\right.$ body weight) (EFSA, 2009).

The contribution of heavy metals to the $\delta^{15} \mathrm{~N}$ signatures in crayfish was estimated through a multiple regression analysis of the five heavy metals analysed over the $\delta^{15} \mathrm{~N}$ signatures of crayfish (pooled individuals of the three sites) as the dependent variable and explained $51 \%$ of the total variation of crayfish $\delta^{15} \mathrm{~N}(r=0.72$, $\left.r^{2}=0.51, F_{(5,34)}=7.35, p<0.0001\right)$. Further multiple regression analyses were performed for each site. Only site 3 showed significant results, with $93 \%$ of the variance in $\delta^{15} \mathrm{~N}$ explained by the heavy metal contents of crayfish and with $\mathrm{Cu}(r=-0.79, p<0.05)$ and $\mathrm{Cd}(r=-0.78$, $p<0.05)$ as the elements that accounted for most of this relationship.

\section{DISCUSSION}

In this study, the spatial variability (between-site differences) was significant for both $\delta^{13} \mathrm{C}$ and $\delta^{15} \mathrm{~N}$ isotope signatures, whereas the temporal variability (between-date differences) was significant only for average $\delta^{15} \mathrm{~N}$ signatures. The pattern of variation of $\delta^{13} \mathrm{C}$ values was related to the variability of the basal food sources (mainly
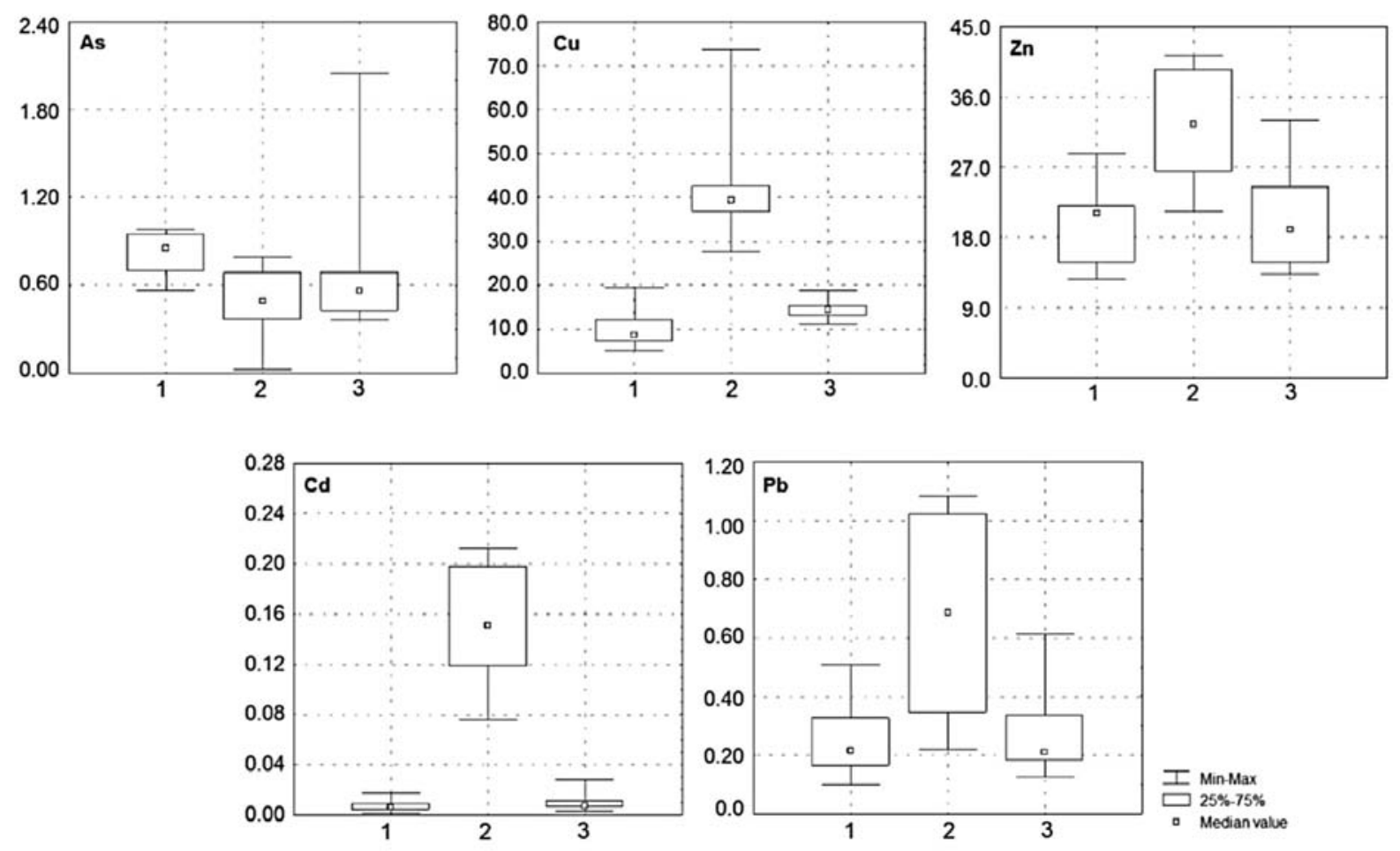

Figure 5. Patterns of variability of five heavy metals analysed in whole body crayfish from the three studied ecosystems, expressed as $\mu \mathrm{g} \cdot \mathrm{g}^{-1}$ fresh weight. Sample sizes of each crayfish sample are given in parentheses for each site. Site $1(\mathrm{n}=10)$; site $2(\mathrm{n}=20)$; site $3(\mathrm{n}=10)$. Patrones de variabilidad de los metales pesados analizados en los cuerpos enteros de cangrejos en los tres ecosistemas estudiados expresados en $\mu \mathrm{g} \cdot \mathrm{g}^{-1}$ peso fresco. El tamaño muestral de los cangrejos analizados se da entre paréntesis para cada estación. Estación $(n=10)$, estación $2(n=20)$; estación $3(n=10)$. 
detritus and primary producers) at each site. The amount of detritus for each sampling site varied depending on the underlying lithology and organic matter inputs from biological communities within the area or nearby (autochthonous or allochthonous inputs, respectively). The $\delta^{13} \mathrm{C}$ values for detritus from sites 1 and 2 (the muddy sites) indicated that the sites were both enriched in carbon and had very similar ranges but differed markedly from the value for sandy site 3 . These values are similar to those found in highly productive freshwater ecosystems that store large amounts of detritus, such as Laguna Madre of Texas $\left(-16 \%\right.$ ) (Fry \& Sherr, 1984). The $\delta^{13} \mathrm{C}$ value for site 3 was lower and more similar to the average values of terrestrial organic matter $(-26 \% 0)$ and estuaries $(-25.8 \% 0)$ in the Delaware estuary, Philadelphia (Cifuentes et al., 1988) or of littoral areas (-29.9\% in Wards Creek, Virginian Atlantic Coast) (Garman \& Macko, 1998).

Helophytes and macrophytes showed smaller $\delta^{13} \mathrm{C}$ values compared with detritus. This effect can be used to estimate the relative importance of these primary producers to herbivores. Allochthonous (Cynodon dactylon) and autochthonous (phytoplankton, periphyton, helophytes) food sources can be easily identified according to their $\delta^{13} \mathrm{C}$ signatures. Because C. dactylon is a gramineous plant with a C-4 photosynthetic pathway, it is expected to have higher $\delta^{13} \mathrm{C}$ values (LaZerte \& Szalados, 1982). This species, which is associated with areas of groundwater discharge, is the only terrestrial plant that remains green throughout the dry season and is an important food source for numerous waterfowl species that live in the area
(González-Bernáldez, 1997). Our isotopic food web models (Figs. 2 and 3, Table 2) are consistent with systems driven by a detritus-based energy pathway (sites 1 and 2) and with a system based on both primary producers and detritus (site 3).

The mean $\delta^{15} \mathrm{~N}$ values for detritus fell within the range observed for other aquatic ecosystems at many sites (3.93-15.70\% in Lake Lugano, Switzerland [Bernasconi et al., 1997]; 5.5$18.7 \%$ in the Delaware estuary [Cifuentes et al., 1988]), suggesting that nitrate is not limiting to primary producers. At each site, the primary producers and consumers showed changes in their $\delta^{15} \mathrm{~N}$ signatures that are consistent with species replacement within the communities that inhabit these ecosystems (see APPENDIX 1). Whereas the $\delta^{15} \mathrm{~N}$ values of species varied significantly between sites, the isotopic signatures of consumers fit well within the ranges of potential food sources at each site. Invertebrates displayed a broad range of trophic strategies including suspension feeders (e.g., copepods or cladocerans), detritivores or 'collectors' (sensu (Merrit and Cummins 1996)) (e.g., dipterans and ostracods), herbivores or 'macrophyte piercers' (Merritt and Cummins, op. cit.) (e.g., mayflies), carnivores (e.g., many heteroptera, coleoptera and odonata), and omnivores (e.g., fish and crayfish). Detritivores and grazers appear to be primarily omnivorous, as indicated by their high $\delta^{15} \mathrm{~N}$ values, which are similar to those of predators. At all sites, the variation in $\delta^{15} \mathrm{~N}$ within trophic levels was low, and trophic levels were not easy to discriminate. The high variation and overlap observed in isotopic signatures (Figs. 2 and 3) showed a group effect for different trophic

Table 2. Contribution of food items to crayfish of the three study sites determined by the concentration-weighted linear mixing model. Contribución de los distintos recursos alimenticios de los tres casos de estudio al cangrejo calculados según un modelo lineal de mezcla ponderado.

\begin{tabular}{ccccl}
\hline Site & Detritus & Primary producers & Invertebrates & Food items included in the model \\
\hline 1 & 0.515 & -0.259 & 0.744 & $\begin{array}{l}\text { detritus, periphyton, shrimps, heteroptera, odonata and } \\
\text { diptera }\end{array}$ \\
2 & 0.637 & 0.020 & 0.343 & $\begin{array}{l}\text { detritus, periphyton, submersed macrophytes, shrimps, } \\
\text { heteroptera and diptera }\end{array}$ \\
3 & 0.737 & 0.246 & 0.017 & $\begin{array}{l}\text { detritus, periphyton, submersed macrophytes, copepoda, } \\
\text { cladocera, shrimps, heteroptera and diptera }\end{array}$ \\
\hline
\end{tabular}


species in the same taxonomic category, which suggests that animals act as opportunistic feeders that focus on food sources according to their availability, as reported in other field studies (Zah et al., 2001).

The gradual enrichment in $\delta^{15} \mathrm{~N}$ values between species in our simplified model suggested that the concept of trophic levels with discrete jumps in trophic position along a food chain is inappropriate. Co-existing species appeared to feed along a continuum of trophic levels, as has been observed in other systems (Hobson et al., 1994; France \& Peters, 1997; Vander Zanden et al., 1999).

The omnivore trophic role of crayfish is particularly relevant in these ecosystems. Gut content studies and stable isotopes analyses have revealed detritus as a major component of the diet of many crayfish species (Creed, 1994; Whitledge \& Rabeni, 1997; GutiérrezYurrita et al., 1998; Alcorlo et al., 2004). Our concentration-weighed mixing isotopic model estimated that the proportions of detritus in crayfish tissues were $63 \%$ and $73 \%$ for sites 2 and 3 , respectively. The fact that crayfish from site 1 did not fall in the mixing triangle (Table 2) suggests that the chosen fractionation factors should be corrected because of the sensitivity of this type of model to the discrimination factors used, as suggested by Bond \& Antony (2011), or that there are no substantial differences in isotopic composition among sources, as suggested by Phillips \& Gregg (2001). There was also a small contribution from other invertebrates, as revealed by their $\delta^{15} \mathrm{~N}$ signatures, which fall within the expected enrichment range of $3.4 \%$ (APPENDIX 2-4). The estimated contribution of primary producers to the crayfish $\delta^{15} \mathrm{~N}$ signal seems to be very small. The $\delta^{13} \mathrm{C}$ signatures of $P$. clarkii revealed that the animals used primary producer food sources in each of the three sites, both autochthonous sources (detritus and the primary producers of the system [phytoplankton, periphyton and helophytes]) and the allochthonous sources (terrestrial submersed vegetation) (Table 2).

In regard to the changes in diet corresponding to the ontogeny of crayfish, it has long been recognised that juveniles of many species feed predominantly on invertebrate prey, whereas adults shift their food requirements to vegetation and detritus (Goddard, 1988; France, 1996b). The stable isotope analysis in the present study did not identify differences in nutritional pathways between crayfish of different sizes (Fig. 4). The ontogenetic shift in diet detected in gut analyses may indicate that lower volumes of invertebrates are able to satisfy the energetic requirements for adult growth (Parkyn et al., 2001). Gut content analyses identify crayfish as omnivores that process detritus and vegetation and prey upon other invertebrates, such as chironomids, water bugs, cladocerans, snails and mayflies (Alcorlo et al., 2004). On the other hand, isotopic signatures indicated that crayfish tend toward a predator position (Figs. 2 and 3). These findings suggest that, despite the use of several food sources, crayfish feed predominantly on animal prey and that these prey are more important in terms of assimilation and incorporation into crayfish biomass. Similar results have been found in studies of other crayfish species, such as Paranephrops planifrons in New Zealand streams (Parkyn et al., 2001; Hollows et al. 2002) and Orconectes nais and $O$. neglectus in a tallgrass prairie stream in Kansas (Evans-White et al., 2001).

We observed a consistent relationship between the concentrations of heavy metals (As, $\mathrm{Cd}, \mathrm{Zn}, \mathrm{Cu}, \mathrm{Pb}$ ) bioaccumulated in crayfish tissues and their nitrogen isotope signatures. This relationship, however, became weak when it was estimated site by site. The metals that have the greatest influence on $\delta^{15} \mathrm{~N}$ are $\mathrm{Cu}$ and $\mathrm{Cd}$, whose accumulation has been found to be dose (i.e., Cd)- and time (i.e., $\mathrm{Cu}$ )-dependent in other studies performed in the area (Alcorlo et al., 2006). The bioaccumulation of different metals by crayfish depends on their environmental concentration and the nature and/or possible role of these metals as essential elements for crayfish metabolism. $\mathrm{Cu}$ is an essential metal whose levels are regulated and controlled within certain limits because it forms part of active enzyme centres and respiratory pigments (Rainbow, 1995), whereas $\mathrm{Cd}$ is a non-essential metal 
(Rainbow, 1997) and tend to be detoxified by metallothionein proteins located in the digestive glands of $P$. clarkii (Del Ramo et al., 1989). These results are related to the different metal assimilation routes used by crayfish, i.e., direct uptake from water or indirect uptake from food.

Given that crayfish behave as polytrophic species (omnivorous) in the systems where they occur establishing a high number of trophic interactions with other biological compartments of the systems; its trophic role has important consequences for the management of the ecosystems where crayfish is present. For example, crayfish can efficiently transport xenobiotic substances throughout the trophic web in polluted areas, such as the one described in this study (González et al., 1985; Hernández et al., 1992). Because crayfish constitute an important food source for vertebrate predators, such as fish (Anguilla anguilla), birds (e.g., Ciconia ciconia in Correia, 2001) and mammals (e.g., Lutra lutra in Delibes \& Adrián, 1987; Palomares \& Delibes, 1991; Beja, 1996) we strongly recommend a long-term monitoring programme to keep track of the transfer of pollutants to higher order food web levels mediated by crayfish.

Finally, we conclude that our isotopic food web models are consistent with systems driven by a detritus-based energy pathway (sites 1 and 2) and with a system based on both primary producers and detritus. The trophic positions estimated for crayfish and other invertebrates at each site were low, suggesting the prevalence of omnivory and the occurrence of a trophic continuum rather than discrete levels. Isotopically, crayfish occupied a predator position in the food webs, consistently with a predominance of animal sources in their diet. However, no significant changes between crayfish ontogenetic stages were found using isotopic ratios in this study. The site with the highest concentration of heavy metals showed $\delta^{13} \mathrm{C}$ and $\delta^{15} \mathrm{~N}$ ratios, and we found a significant correlation between five heavy metal elements (As, $\mathrm{Cd}, \mathrm{Zn}$. $\mathrm{Cu}, \mathrm{Pb}$ ) measured in crayfish and their nitrogen isotope signatures $(r=0.72$, $p<0.0001)$. These findings support the role of $P$. clarkii as a pollution biomarker.

\section{ACKNOWLEDGEMENTS}

We are indebted to Dr. Keith Hobson (Canadian Wildlife Service, Saskatchewan), who kindly reviewed the original manuscript and made positive comments and useful suggestions. Prof. C. Montes (Ecology Dept., UAM) is acknowledged as the Scientific Head of the "Guadiamar Basin Green Corridor Panel" for offering us the chance to participate in the project. We thank Miguel Angel Bravo, Yolanda Díaz, Héctor RodríguezPérez, Jorge R. Sánchez and particularly Marina Otero for their valuable assistance with field collections. Dr. Antonio Quesada (Biology Dept., UAM) provided access to the analytical mill. The stable isotopes analyses were performed by $\mathrm{R}$. Redondo (Interdepartmental Research Service, SidI, UAM). This study was supported by the FEDER funded project "Bioaccumulation and transformation of heavy metal and arsenic levels by Red Swamp Crayfish (Procambarus clarkii) populations living in the area affected by the Aznalcóllar mine accident and their implications for human consumption". P. Alcorlo was supported by a postdoctoral grant from the Autonomous Community of Madrid and the European Social Fund during 2000-2003.

\section{REFERENCES}

ADRIAN, M. I. \& M. DELIBES. 1987. Food habits of the otter (Lutra lutra) in two habitats of the Doñana National Park, SW Spain. Journal of Zoology, 212: 399-406.

ALCORLO, P., W. GEIGER \& M. OTERO. 2004. Feeding preferences and food selection of the red swamp crayfish, Procambarus clarkii, in habitats differing in food item diversity. Crustaceana, 44: 435-453.

ALCORLO, P., M. OTERO, M. CREHUET. A. BALTANÁS \& C. MONTES. 2006. The use of the red swamp crayfish (Procambarus clarkii, Girard) as indicator of the bioavailability of heavy metals in environmental monitoring in the River Guadiamar (SW, Spain). Science of the Total Environment, 366: 380-390.

ALLISON, G., L. J. B. LAURENSON, G. PISTONE, F. STAGNITTI \& P. L. JONES. 2000. Effects of 
dietary copper on the Australian Freshwater Crayfish Cherax destructor. Ecotoxicology and Environmental Safety, 46: 117-123.

ALONSO, F., C. TEMIÑO \& J. DIÉGUEZ-URIBEONDO. 2000. La situation de l'écrevisse à pieds blancs, Austropotamobius pallipes (Lereboullet, 1858), en Espagne: répartition et législation. Bulletin FranÇais De La Pêche Et De La Pisciculture, 356: 31-54.

ANASTÁCIO, P. M. \& J. C. MARQUES. 1995 Population Biology and production of the red swamp crayfish Procambarus clarkii (Girard) in the lower Mondego river Valley, Portugal, Journal of Crustacean Biology, 15: 156-168.

ANDERSON, M. B., P. REDDY, J. E. PRESLAN, M. FINGERMAN, J. BOLLINGER, L. JOLIBOIS, G. MAHESHWARUDU \& WJ. GEORGES. 1997a. Metal accumulation in crayfish, Procambarus clarkii, exposed to a petroleum-contaminated Bayou in Louisiana. Ecotoxicology and Environmental Safety, 37: 267-272.

ANDERSON, M. B., J. E. PRESLAN, L. JOLIBOIS, J. BOLLINGER \& W. J. GEORGES. 1997b. Bioaccumulation of lead nitrate in Red Swamp Crayfish (Procambarus clarkii). Journal of Hazardous Materials, 154: 15-29.

ANGELER, D., S. SÁNCHEZ-CARRILLO, G. GARCÍA \& M. A. COBELAS. 2001. The influence of Procambarus clarkii (Cambaridae, Decapoda) on water quality and sediment characteristics in a Spanish floodplain wetland. Hydrobiologia, 464: 89-98.

ANTÓN, A., T. SERRANO, E. ANGULO, G. FERRERO, A. RALLO. 2000. The use of two species of crayfish as environmental quality sentinels: the relationship between heavy metal content, cell and tissue biomarkers and physico-chemical characteristics of the environment. Science of the Total Environment, 247: 239-251.

BEJA, P. R. 1996. An analysis of otter Lutra lutra predation on introduced american crayfish Procambarus clarkii in Iberian streams. Journal of Applied Ecology, 33: 1156-70.

BEN-DAVID, M. \& D. M. SCHELL. 2001. Mixing models in analyses of diet using multiple stable isotopes: a response. Oecologia, 127, 180-184.

BERNASCONI, S. M., A. BARBIERI \& M. SIMONA. 1997. Carbon and nitrogen isotope variations in sedimenting organic matter in Lake Lugano. Limnology and Oceanography, 42: 1755-1765.
BOND, A. L. \& W. D. ANTONY. 2011. Recent Bayesian stable-isotope mixing models are highly sensitive to variation in discrimination factors. Ecological Applications, 21(4): 1017-1023.

BOON P. I. \& S. E. BUNN. 1994. Variations in the stable isotope composition of aquatic plants and their implications for food web analysis. Aquatic Botany, 48: 99-108.

BROWN, P. B. 1990 Review of crayfish nutrition. Crustacean Nutrition Newsletter, 6: 68-69.

CANO, E. \& M. E. OCETE 1997. Population biology of red swamp crayfish, Procambarus clarkii (Girard, 1852) in the Guadalquivir river marshes. Spain. Crustaceana, 70: 553-561.

CIFUENTES, L. A., J. H. SHARP \& M. L. FOGEL. 1988. Stable carbon and nitrogen isotope biogeochemistry in the Delaware estuary. Journal of the North American Benthological Society, 33: 11021115.

CORREIA, A. M. 2001. Seasonal and interspecific evaluation of presation by mammals and birds on the introduced red swamp crayfish Procambarus clarkii (Crustacea, Cambaridae) in a freshwater marsh (Portugal). Journal of Zoology, London, 255: 533-41.

CREED, R. P. 1994. Direct and indirect effects of crayfish grazing in a stream community. Ecology, 75: 2091-2103.

D’ABRAMO L. R. \& E. H. ROBINSON. 1989. Nutrition of crayfish. Aquatic Science, 1: 711-728.

DEL RAMO, J., A. PASTOR, A. TORREBLANCA, J. MEDINA \& J. DÍAZ-MAYANS. 1989. Cadmium-Blinding proteins in midgut gland of freshwater crayfish Procambarus clarkii. Bulletin of Environmental Contamination and Toxicology, 42: 241-246.

DELIBES, M. \& I. ADRIÁN 1987. Effects of crayfish introduction on otter Lutra lutra in the Doñana National Park, SW Spain. Biological Conservation, 42: 153-159.

DENIRO, M. J. \& S. EPSTEIN. 1978. Influence of diet on the distribution of carbon isotopes in animals. Geochimica Et Cosmochimica Acta, 42: 495-506.

DENIRO, M. J. \& S. EPSTEIN. 1981. Influence of diet on the distribution of nitrogen isotopes in animals. Geochimica Et Cosmochimica Acta, 45: 341-351.

EFSA-Panel on Contaminants in the Food Chain (CONTAM). 2009. Scientific Opinion on Arsenic in Food. EFSA Journal; 7(10): 1351. [199 pp.]. 
doi:10.2903/j.efsa.2009.1351. Available online: www.efsa.europa.eu.

EVANS-WHITE, M., W. K. DODDS, L. J. GRAY \& K. M. FRITZ. 2001 A comparison of the trophic ecology of the crayfishes (Orconectes nais (Faxon) and Orconectes neglectus (Faxon)) and the central stoneroller minnow (Campostoma anomalum (Rafinesque)): omnivory in a tallgrass prairie stream. Hydrobiologia, 462: 131-144.

FARIA, M., D. HUERTAS, D. X. SOTO, J. O GRIMALT, J. CATALAN, M. C. RIVA \& C. BARATA, 2010. Contaminant accumulation and multi-biomarker responses in field collected zebra mussels (Dreissena polymorpha) and crayfish (Procambarus clarkii), to evaluate toxicological effects of industrial hazardous dumps in the Ebro river (NE Spain). Chemosphere; 78: 232-240.

FEMINELLA, J. W. \& V. H. RESH. 1986. Effects of crayfish grazing on mosquito habitat at Coyote Hills Marsh. In: Proceedings and Papers of the Fifty-Fourth Annual Conference of the California Mosquito and Vector Control Association. The 54th Annual Conference of the California Mosquito and Vector Control Association, University of California, USA: 101-103.

FEMINELLA, J. W. \& V. H. RESH. 1989. Submerged macrophytes and grazing crayfish: an experimental study of herbivory in California freshwater marsh. Holartic Ecology, 12: 1-8.

FRANCE, R. L. 1996a. Ontogenetic shift in crayfish $\delta^{13} \mathrm{C}$ as a measure of land-water ecotonal coupling. Oecologia, 107: 239-242.

FRANCE, R. L. 1996b. Benthic-pelagic uncoupling of carbon flow. Trends in Ecology and Evolution, 11: 471.

FRANCE, R. L. 1999. Relationships between DOC concentration and epilithon stable isotopes in boreal lakes. Freshwater Biology, 41: 101-105.

FRANCE, R. L. \& R. H. PETERS. 1997. Ecosystem differences in the trophic enrichment of ${ }^{13} \mathrm{C}$ in aquatic food webs. Canadian Journal of Fisheries and Aquatic Sciences, 54: 1255-1258.

FRY, B. \& E. B. SHERR. 1984. $\delta^{13} \mathrm{C}$ measurements as indicators of carbon flow in marine and freshwater ecosystems. Contributions in Marine Science, 27: $13-47$.

GANNES L. Z., C. M. RÍO \& P. KOCH. 1998. Natural abundance variations in stable isotopes and their potential uses in animal physiological ecology. Comparative Biochemistry Physiology, 119: 725-737.
GARMAN, G. C. \& S. A. MACKO. 1998. Contribution of marine-derived organic matter to an Atlantic coast, freshwater, tidal stream by anadromous clupeid fishes. Journal of The North American Benthological Society, 17: 277-285.

GEARING J. N., P. J. GEARING, D. T. RUDNICK, A. G. REQUEJO \& M. J. HUTCHINS. 1984. Isotopic variability of organic carbon in a phytoplankton-based temperate estuary. Geochimica Et Cosmochimica Acta, 48: 1089-1098.

GEIGER, W., P. ALCORLO, A. BALTANÁS \& C. MONTES. 2005. Impact of an introduced Crustacean on the trophic webs of Mediterranean wetlands. Biological Invasions, 7: 49-73.

GHERARDI, F. \& S. BARBARESI. 2000. Invasive crayfish: activity patterns of Procambarus clarkii in the rice fields of the Lower Guadalquivir (Spain). Archiv fur Hydrobiologie, 150: 153-168.

GODDARD, J. S. 1988. Food and feeding. In: Freshwater Crayfish Biology, Management and Exploitation. Holdich, D.M. \& R.S. Lowery (eds): 145-166. Croom-Helm Timber Press, London.

GONZÁLEZ-BERNÁLDEZ, F. 1997. Gramíneas pratenses de Madrid, Consejería de Medio Ambiente y Desarrollo Regional de la Comunidad Autónoma de Madrid, 287 pp.

GONZÁLEZ, J., L. M. HERNÁNDEZ, A. HERNÁN \& G. BALUJA. 1985. Multivariate analysis of water contamination by heavy metals at Doñana National Park. Bulletin of Environmental Contamination \& Toxicology, 35: 266-271.

GUTIÉRREZ-YURRITA, P. J., G. SANCHO, M. A. BRAVO, A. BALTANÁS \& C. MONTES. 1998. Diet of the red swamp crayfish Procambarus clarkii in natural ecosystems of the Doñana National Park temporary fresh-water marsh (Spain). Journal of Crustacean Biology, 14: 120-127.

GUTIÉRREZ-YURRITA, P. J., J. M. MARTÍNEZ, M. A. BRAVO-UTRERA, C. MONTES, M. ILHÉU \& J. M. BERNARDO. 1999. The status of crayfish populations in Spain and Portugal. In: Crayfish in Europe as alien species. F. Gherardi \& D.M. Holdich (eds): 161-192. Balkema AA, Rotterdam.

HABSBURGO-LORENA, A. S. 1983. Socioeconomic aspects of the crawfish industry in Spain. Freshwater Crayfish, 5: 552-554.

HERNÁNDEZ, L. M., M. A. FERNÁNDEZ \& M. J. GONZÁLEZ. 1992. Organochlorine pollutants in water, soils and earthworms in the Guadalquivir 
river, Spain. Bulletin of Environmental Contamination \& Toxicology, 49: 192-198.

HERSHEY, A. E. \& B. J. PETERSON. 1996. Stream food webs. In: Methods in stream ecology F.R. Hauer \& G.A. Lamberti (eds): 511-529. Academic Press, San Diego, California.

HOBSON, K. A. \& H. E. WELCH. 1992. Determination of trophic relationships within a high Artic marine food web using $\delta^{13} \mathrm{C}$ and $\delta^{15} \mathrm{~N}$ analysis. Marine Ecology Progress Series, 84: 9-18.

HOBSON, K. A., J. F. PIATT \& J. PITOCCHELLI. 1994. Using stable isotopes to determine seabirds trophic relationships. Journal of Animal Ecology, 63: 786-798.

HOLLOWS, J. W., C. R. TOWNSEND \& K. J. COLLIER. 2002. Diet of crayfish Paranephrops zealandicus in bush and pasture streams: insights from stable isotopes and stomach analysis. New Zealand Journal of Marine and Freshwater Research, 36: 129-142.

ILHÉU, M. \& J. M. BERNARDO. 1993. Experimental evaluation of food preference of red swamp crayfish, Procambarus clarkii: Vegetal versus animal. Freshwater Crayfish, 9: 359-364.

ILHÉU, M. \& J. M. BERNARDO. 1995. Trophic ecology of red swamp crayfish Procambarus clarkii (Girard)-Preferences and digestibility of plant foods. Freshwater Crayfish, 10: 132-139.

INGER, R. \& S. BEARHOP. 2008. Applications of stable isotope analysis to avian ecology. Ibis, 150: 447-461.

JONES, J. I. \& S. WALDRON. 2003. Combined stable isotope and gut contents analysis of food webs in plant-dominated, shallow lakes. Freshwater Biology, 48: 1396-1407.

KWAK, T. J. \& J. B. ZEDLER. 1997. Food web analysis of southern California coastal wetlands using multiple stable isotopes. Oecologia, 110: 262-277.

LAJTHA, K. \& R. H. MICHENER. 1994. Introduction. In: Stable isotopes in ecology and environmental science K. Lajtha \& R.H. Michener (eds.). Blackwell Scientific Publications, London, U.K.

LAZERTE, B. D. \& J. E. SZALADOS. 1982. Stable carbon isotope ratio of submerged freshwater macrophytes. Limnology and Oceanography, 27: 413-418.

MARANHÃO, P., J. C. MARQUES \& V. MADEIRA. 1995. Copper concentrations in soft tissues of the red swamp crayfish Procambarus clarkii (Girard,
1852), after exposure to a range of dissolved copper concentrations. Freshwater Crayfish, 10: 282286.

MARTÍNEZ DEL RIO, C., N. WOLF, S. A. CARLETON, \& L. Z. GANNES. 2009. Isotopic ecology ten years after a call for more laboratory experiments. Biological Reviews of the Cambridge Philosophical Society, 84: 91-111.

MARTÍN-DÍAZ, M. L., S. R. TUBERTY, C. MCKENNEY, J. BLASCO, C. SARASQUETE \& T. A. DEL VALLS. 2006. The use of bioaccumulation, biomarkers and histopathology diseases in Procambarus clarkii to establish bioavailability of $\mathrm{Cd}$ and $\mathrm{Zn}$ after a mining spill. Environmental Monitoring and Assessment, 116 (1-3): 169-184.

MEHARG, A. A., D. OSBORN, D. J. PAIN, A. SÁNCHEZ \& M. A. NAVESO. 1999. Contamination of Doñana food-chains after the Aznalcóllar mine disaster. Environmental Pollution, 105: 387-390.

MERRIT, R. W. \& K. W. CUMMINS. 1996. An Introduction to the Aquatic Insects of North America: 3rd Edition. Kendall/Hunt publishing company.

MINAGAWA, M. \& E. WADA. 1984. Stepwise enrichment of ${ }^{15} \mathrm{~N}$ along food chains: Further evidence and the relation between $\delta^{15} \mathrm{~N}$ and animal age. Geochimica Et Cosmochimica Acta, 48: 1135-1140.

MONTES, C., M. A. BRAVO-UTRERA, A. BALTANÁS, C. DUARTE \& P. J. GUTIÉRREZ-YURRITA. 1993. Bases ecológicas para la gestión del cangrejo rojo de las marismas del Parque Nacional de Doñana, España. Madrid, España: ICONA.

MONTES, C., F. BORJA, M. A. BRAVO \& J. M. MOREIRA. 1998. Reconocimiento biofísico de espacios naturales protegidos. Doñana: una aproximación ecosistémica. Consejería de Medio Ambiente, Junta de Andalucía, España. 311 pp.

NAQVI, S. M. \& C. T. FLAGGE. 1990. Chronic effects of arsenic on American red crayfish, Procambarus clarkii, exposed to Monosodium Methanearsonate (MSMA) Herbicide. Bulletin of Environmental Contamination \& Toxicology, 45: 101-106.

NAQVI, S. M. \& R. D. HOWELL. 1993. Toxicity of cadmium and lead to juvenile red swamp crayfish, Procambarus clarkii, and effects on fecundity of adults. Bulletin of Environmental Contamination \& Toxicology, 51: 303-308.

NATIONAL PESTICIDE INFORMATION CENTER. http://npic.orst.edu/ingred/aifact.html (last visit 17th july 2012). 
PAINE, R. T. 1988. Food webs: road maps of interactions or grist for theoretical deveplopment? Ecology, 69, 1648-1654.

PALOMARES F. \& M. DELIBES 1991. Alimentación del meloncillo Herpestes ichneumon y de la gineta Genetta genetta en la Reserva Biológica de Doñana, S.O. de la Peninsula Ibérica. Doñana Acta Vertebrata, 18: 5-20.

PARKYN, S. M., K. J. COLLIER \& B. J. HICKS. 2001. New Zealand stream crayfish: functional omnivores but trophic predators? Freshwater Biology, 46: 641-652.

PETERSON, B. J., R. W. HOWARTH \& R. H. GARRITT. 1985. Multiple stable isotopes used to trace the flow of organic matter in estuarine food webs. Science, 227: 1361-1363.

PETERSON, B. J. \& B. FRY. 1987. Stable isotopes in ecosystem studies. Annual Reviews of Ecology and Systematics, 18: 293-320.

PHILLIPS, D. L. 2001. Mixing models in analyses of diet using multiple isotopes: a critique. Oecologia, 127: 166-170.

PHILLIPS, D. L. \& J. W. GREGG. 2001. Uncertainty in source partitioning using stable isotopes. $\mathrm{Oe}$ cologia, 127: 171-179.

PHILLIPS, D. L. \& P. L. KOCH. 2002. Incorporating concentration dependence in stable isotope mixing models. Oecologia, 130: 114-125.

PONSARD, S. \& R. ARDITI. 2001. Detecting omnivory with $\delta^{15} \mathrm{~N}$. Trends in Ecology and Evolution, 16: 20-21.

PRAT, N., J. TOJA, C. SOLÀ, M. D. BURGOS, M. PLANS \& M. RIERADEVALL. 1999. Effect of dumping and cleaning activities on the aquatic ecosystems of the Guadiamar River following a toxic flood. The Science of the Total Environment, 242: 231-248.

RAINBOW, P. S. 1995. Physiology, Physicochemistry and metal uptake: a crustacean perspective. Marine Pollution Bulletin, 31: 55-59.

RAINBOW, P. S. 1997. Ecophysiology of trace metal uptake in Crustaceans. Estuarine Coastal and Shelf Science, 44: 169-175.

RODRÍGUEZ, C. F., E. BECARÉS \& M. FERNÁNDEZ-ALÁEZ. 2003. Shift from clear to turbid phase in lake Chozas (NW Spain) due to the introduction of American red swamp crayfish (Procambarus clarkii) . Hydrobiologia, 506-509: 421-426.

SCHILDERMAN, P. A. E. L., E. J. C. MOONEN, L.
M. MAAS, I. WELLE \& J. C. S. KLEINJANS. 1999. Use of crayfish in biomonitoring studies of environmental pollution of the River Meuse. Ecotoxicology and Environmetal Safety, 44: 241-252.

SCHLENK, D. 1999. Necessity of defining biomarkers for use in Ecological Risk Assessment. Marine Pollution Bulletin, 39(1-12): 48-53.

SENRA, A. \& E. E. ALÉS. 1992. The decline of white stork Ciconia ciconia population of western Andalusia between 1976 and 1988: causes and proposals for conservation. Biological Conservation, 61: 51-57.

SUÁREZ-SERRANO, A., C. ALCARAZ, C. IBÁŃEZ, R. TROBAJO \& C. BARATA. 2010. Procambarus clarkii as a bioindicator of heavy metal pollution sources in the lower Ebro River and Delta. Ecotoxicology and Environmental Safety, 73: 280-286.

TABLADO, Z., J. L. TELLA， J. A. SÁNCHEZZAPATA \& F. HIRALDO. 2010. The paradox of the long-term positive effects of a North American crayfish on a European Community of predators. Conservation Biology, 24: 1230-1238.

VANDER ZANDEN, M. J., J. M. CASSELMAN \& J. B. RASMUSSEN. 1999. Stable isotope evidence for the food web consequences of species invasions in lakes. Nature, 401: 464-469.

VIOQUE-FERNÁNDEZ, A., E. ALVES DE ALMEIDA, J. BALLESTEROS, T. GARCÍA-BARRERA, J. L. GÓMEZ-ARIZA \& J. LÓPEZ-BAREA. 2007. Doñana National Park survey using crayfish (Procambarus clarkii) as bioindicator: esterase inhibition and pollutant levels. Toxicology Letters, 168: 260-268.

VIOQUE-FERNÁNDEZ, A., E. ALVES DE ALMEIDA \& J. LÓPEZ-BAREA. 2009. Assessment of Doñana National Park contamination in Procambarus clarkii: Integration of conventional biomarkers and proteomic approaches. The Science of the Total Environment, 407(5): 1784-1797.

WHITLEDGE, G. W. \& C. F. RABENI. 1997. Energy sources and ecological role of crayfishes in an Ozark stream: insights from stable isotopes and gut analysis. Canadian Journal of Fisheries and Aquatic Sciences, 54: 2555-2563.

ZAH, R., P. BURGHERR, S. M. BERNASCONI \& U. UEHLINGER. 2001. Stable isotope analysis of macroinvertebrates and their food sources in a glacier stream. Freshwater Biology, 46: 871-882. 